Trivent Publishing

(C) The Authors, 2018

Available online at http:/ / trivent-publishing.eu/

TRIVENT

Series: Applied Ethics: From Bioethics to Environmental Ethics

\title{
Legal and Ethical Rules of Performing Medical Professions in Poland
}

\author{
Jakub Berezowski \\ Państwowa Wyższa Szkoła Zawodowa w Raciborzu, \\ State University of Applied Sciences in Racibórz, Poland
}

Abstract: The scope of the regulation of medical professions in Poland is relatively wide. On the one hand, it refers to the medical activity, which consists of the provision of health services; while on the other hand, it refers to competences appropriate for particular medical professions. In the Polish legal system, some medical professions benefit from corporate freedom. These occupations include: doctor, dentist, nurse, midwife, and - until recently - physiotherapist. The tasks of corporations in the medical professions are extensive and consist primarily in the pursuit of the profession of custody. Adherence to professional self-government means that a medical profession is self-reliant in the decision-making process and providing health care services. There seems to be a legitimate postulate of work to increase the scope of regulation of medical procedures. On the one hand, procedures will increase the safety of patients; on the other, they will increase the safety of people performing medical occupations.

Keywords: medical law; medical occupations; doctor; nurse; physiotherapist.

This is an Open Access article distributed in accordance with the Creative Commons Attribution Non Commercial (CC-BY-NC-ND 4.0) license, which permits others to copy or share the article, provided original work is properly cited and that this is not done for commercial purposes. Users may not remix, transform, or build upon the material and may not distribute the modified material (bttp:/ / creativecommons.org/licenses/by-nc/4.0/) 


\title{
Legal and Ethical Rules of Performing Medical Professions in Poland
}

\author{
Jakub Berezowski
}

\section{Introduction}

There is no definition of normative medical profession and medicine in Polish law. The concepts of health and its protection have not been normalized yet. In this respect, the definition of doctrine is still used, but it is justified by the great changing dynamics of these concepts. The absence of these definitions compensates for the relatively comprehensive definition of health benefits and health care benefits. The medical profession (in great simplification) means the provision of health services according to $2 \mathrm{sec}$. 1 point 10 of the Act of April 15, 2015 on medical activity (Journal of Laws, No. 112, item 654, as amended) and consists of actions aimed at the preservation, rescue, restoration, or improvement of health and other medical activities resulting from the treatment process or separate regulations governing their execution. At present, the medical professions, in addition to that of physiotherapist, the Polish legal system includes: doctors, dentists, nurses, midwives, medical rescuers, pharmacists, laboratory diagnosticians. This catalogue of occupations has consisted of main medical occupations, alongside ancillary professions, including technical occupations such as: dentist technician, analyst technician, radiologist technician, etc. [4, p.50]. The medical activity in Poland is regulated by numerous legal acts. On the one hand, the provision of health services requires appropriate legal forms for operators, and on the other hand, health service providers must prove their competence and qualifications.

Today, almost all medical professions in Poland are regulated professions, which results in the necessity of meeting the statutory prerequisites to obtain the confirmation of the right to practice. The necessity to regulate the right to practice is primarily due to the specific nature of the medical profession, which consists in the provision of health services. The provision of medical benefits needs to acquire relevant qualifications which will enable practice in relation to the patients. Performing medical professions are required to demonstrate the utmost care for the health and lives of patients. The treatment is usually a difficult and complicated process which causes the patient a lot of stress and suffering both mentally and physically. Patient care is a particular task which 


\section{Jakub Berezowski \\ Legal and Ethical Rules of Performing Medical Professions in Poland}

needs special normalization. The regulations should consider both the standards of competence and ethics. It is also necessary to set up regulators to define the requirements for providing health care and the necessary professional skills.

The Constitution of the Republic of Poland in Art. 17 sec. 1 (passed on April, 1997 by the National Assembly; OJ, No.7, pos. 4830) provides the possibility of creating a professional self-government, which would deal with the profession and its special requirements on behalf of the state. Custody refers to the correct, lawful performance of professional duties as well as to meeting the highest ethical requirements. The custody of profession, entrusted to an independent corporation, should be done in an extremely responsible way: on the one hand, it should maintain the independence of the professional selfgovernment in relation to public authorities; and the other hand, it should be done in a way that would defend the public interest.

In carrying out the constitutional legislations, many professional groups entrusted the establishment of professional corporations. Over the years, the Polish Parliament enacted a number of laws appointing professional associations a number of professions, including medical professions. At the same time, independence is understood here as an independent intellectual process associated with the performance of professional activities involving decisions based on experience and qualifications of substance. It may be argued that the process of extracting professional corporations is a continuous process because every few years new regulations are written, despite the call for deregulation in the economic sphere. What is extremely important is that professional associations, including medical corporations have been authorized by the legislature to create a code of ethical standards binding its members. These directory standards form a substantially and universally binding law. On the one hand, there are the recipients of professional services, and on the other one, there is the basis for disciplinary responsibility, which is also involved in professional associations.

\section{The road to medical professional corporations in Poland}

The legal basis for the functioning of independent medical professions in Poland is contained in a few legal acts. It should be noted here that this is a profession which entitles provision of health care services on its own behalf in terms of normative competence. The history of professional self-reliance based on the corporate freedom of professional self-government was relatively long and varied in relation to different professions.

The corporation of doctors and dentists was the first to gain freedom and professional autonomy which was a natural process. Currently, this corporation operates under two acts: the Act of December 5, 1996, act on doctor and 
dentist professions (Journal of Laws No. 28, item 152, as amended), and the Act of December 2, act on medical chambers (Journal of Laws No. 219, item 1708 , as amended). The norms of doctors were primitive to all medical professions. Two legal acts regulating the pursuit of the physician were enacted in post-partition Poland. The first law was the Act of December 2, 1921 concerning the pursuit of medical practice in the State of Poland Journal of Laws of 1921, No. 105, item 752) and the second law was the Act of December 1, 1921 on the system and scope of medical chambers operation (Journal of Laws of 1921, No. 105, item 763).

In the case of nurses and midwives, corporate self-reliance in Poland is a relatively new phenomenon. The first comprehensive statute regulating these professions was passed on July 5, 1996 on the Nursing and Midwifery Professions Act (Journal of Laws of 2009, No. 151, item 1211, as amended). Currently, the Act of July 152011 on nursing midwifery occupations (Journal of Laws No. 174, item 1039) is in force, which has replaced the 1996 law.

The most recent corporation is the self-government of physiotherapists. The regulation of the professional competence of physiotherapists was postulated for many years. Finally, the passed bill was a parliamentary project in which a group of deputies recommended the regulation of the professional competence of physiotherapists. The rationale for the bill abounded in a number of arguments in favour of the special regulation of the conditions and principles of pursuit and thus the need to create a new professional corporation. Designers, above all, demonstrated that the physiotherapist profession is medical, which gives it a unique social character. There is no doubt that physiotherapists should show particular psychophysical characteristics and a high level of professional ethics. It is also important, as for every medical profession, to improve professional qualifications based on the latest medical knowledge and technology.

Until the Physiotherapist Act entered into force, physiotherapy activities were not regulated and physiotherapeutic activities could in fact be carried out by persons without professional qualifications, which unfortunately happened often. In practice, in order to pursue physiotherapeutic activities, it was enough to start a business activity and meet the conditions regulated by the Law of July 2, 2004 on the freedom of economic activity (OJ No. 101, item 1178, as amended).

The bill regulates in a complete way the profession of physiotherapist, as well as the rules of its execution. The construction of the bill is close to the standard of performing other medical professions such as those of doctors, dentists, nurses or midwives. What is important is that the legislator established the professional self-government in an unambiguous way in terms of the emergence of a new corporation -- not with regard to the interest of the selfgovernment members, but also to the ethical standards affecting the regulation 
of competence standards and affecting the process of education.

The need for such solutions was questioned and will certainly continue to be debated. In the position of the Presidium of the General Medical Council, while questioning the need to give physiotherapists public trust, we read:

The Presidium of the General Medical Council does not question the purpose of the statutory regulation of the physiotherapist profession. However, in the opinion of the Presidium of the General Medical Council, the project of recognition of the profession of physiotherapist as a profession of public trust and the establishment of professional self-governing people of this profession raises doubts. The profession of public trust consists of professions which perform tasks of a particular character from the point of view of public tasks and from the concern of pursuing the public interest [8].

In addition, this view highlights that the pursuit of public trust professions require the establishment of professional ethics, vows, corporate traditions, and it requires special professional and moral qualifications from its members. According to the Presidium of the General Medical Council, the position is in line with the ruling of the Constitutional Court of July 2, 2007 (file No. K 41/05).

The need for the regulation of the physiotherapist was also questioned on the same grounds on the project of the bill. The reviewer stated that there are no clear and valid arguments in favour of the creation of a professional selfgovernment of physiotherapists, and that the current provisions clearly define the requirements which must be fulfilled for the pursuit of the profession of physiotherapist [9].

\section{The scope of the competencies of medical corporations}

The role of professional corporations in the Polish legal and health care systems remains significant. The scope of corporate competences is wide and the basic tasks of medical self-governments are:

- issuing decisions to confirm the right to pursuit the profession

- supervising the regularity of profession pursuit

- representing corporate interests to the executive and legislative branches

- raising the professional qualifications of corporate members

- passing codes of professional ethics

- engaging in professional responsibility

- organization and conduct of disciplinary judiciary

Such tasks require that the corporation actively and responsibly appoints 
functioning authorities, whose competence is regulated by law. In the case of the nursing and medical corporations, the authorities operate on both the central and the regional level. So far, the shape of the corporate body of physiotherapists leaves the activity of the authorities only on central level. However, the development of this self-governing body may result in the need of statutory changes and the appointment of regional authorities.

The need to distinguish professional medical corporations is justified primarily by the autonomy of the medical professions, as well as by the support given to the pursuit of a profession of public trust. The statutory definition of professional independence of physiotherapists is essentially connected to entrusting many functions to professional self-government. Such norms refer to professions of public trust which use a certain sphere of independence. These professions are also commonly referred to, in colloquial language, as "liberal" and benefit from legal elements of corporate autonomy. According to D. Karkowska, the characteristics of a liberal medical profession include, among other things, the protection of goods, intellectual independence, or individual relations with the patient [4, p. 34]. In my opinion, an essential feature of liberal professions is the real corporate independence. The objectives of the establishment and functioning of the corporation involve legal and organizational independence from public authorities, whose interference is limited to professional self-government, which is gaining regulatory, supervisory, judicial registration, and legislative functions. Although prerogative power is limited to corporate members, in practice they go much deeper. The impact of professional self-government in the legislative sphere is not overestimated. Strong corporate authorities successfully shape regulations not only for their own organization but also for the whole health care system.

For corporate self-government, it is also important to fulfil representative functions with respect to public authorities and society. This includes not only public administration but also local and regional authorities, as well as other professional corporations. The problem of negative corporate impact is extremely current, which could lead to the closure of corporations for new members. This is the place for state actions, which take care of the correct implementation of the constitutional custody mission for proper occupation by professional corporations.

A particularly important function of self-government is competence in the essence of normative character, which consists in shaping the principles of professional ethics. So far, the self-governments of doctors and dentists and the self-government nurses and midwives have set up their own ethical codes. In the near future, physiotherapists are expected to adopt the rules of professional deontology. Ethical standards not only determine the rules of the profession but also give disciplinary responsibility in the event of their violation. 


\section{Jakub Berezowski \\ Legal and Ethical Rules of Performing Medical Professions in Poland}

Professional self-governments also gain the powers delegated by public authorities to become the same administrative bodies on behalf of the state. This dimension of self-government seems to be most important because it involves the transfer of trust to self-government bodies, whose decisions are binding not only for the members of the self-government but also directly to other persons and above all the recipients of the benefits provided by physiotherapists. J. Boć states that

the division of powers between the organizational forms (organs) of the self-government and the organs of government administration that pursue supervision over the self-government or other organs of the public administration is a task of the legislator, and these competencies must be distinguished dichotomously [1, p. 48].

\section{The main features of medical professions}

Medical professions are regulated occupations. The definition of a regulated profession is readable in art. 5 Act of December 22, 2015 on the recognition of professional qualifications acquired in the Member States (Journal of Laws 2016, Item 65). It is defined as a set of professional activities whose performance is conditioned by the possession of formal qualifications required for the performance of these professional activities - this is required, subject to fulfilment of other conditions specified in these provisions. It should also be noted that regulated professions have been introduced in the Polish legal system by EU law and above all by the Directive 2005/36/ EC of the European Parliament and of the Council on September 7, 2005 on the recognition of professional qualifications. Since then, the European definition of regulated profession has been in force, $3 \mathrm{sec} .1$ point of the directive. According to it, a regulated profession is a professional activity or a group of professional activities which, directly or indirectly, by virtue of laws, regulations or administrative provisions, have a special professional qualification; in particular, the use of a professional title is reserved solely under the laws, regulations, and administrative provisions for persons with appropriate professional qualifications.

The principle of professional independence according to D. Karkowska: "... is connected to the legal obligation of the 'personal' pursuit of the profession regardless of the legally permissible form of professional practice." [4, p. 259]. Independence as understood above refers primarily to the intellectual decision-making process which must provide medical services by persons who pursuit the medical profession. The decision-making process is primarily based on qualifications and professional experience. Professional independence does not mean that there are no normative limitations. These restrictions are in- 
cluded in a number of legal acts regulating the profession and above all in the commented law.

The definition of a liberal profession has not been normatively established in a way that it could provide a definition which will be universally applicable. Art. $17 \mathrm{sec} .1$ of the Constitution of the Republic of Poland constructs only the concept of the profession of public trust, which should not be equated with a liberal profession. The current provisions apply to the concept of a liberal profession in four cases [3, p. 93]. First of all, this concept is defined by Art. 4 sec. 1 u.p.d. where a liberal occupation is a non-agricultural business carried out personally by doctors, dentists, veterinarians, dental technicians, fleeces, midwives, nurses, translators, and teachers in the provision of educational services consisting in giving lessons per hour if the activity is not carried out in favour of legal persons and organizational units without legal personality or for natural persons for the purposes of their non-agricultural economic activity, but for the personal pursuit of a liberal profession be carried out without employment on the basis of employment contracts, contracts of engagement, work contracts, and other contracts of a similar nature to people who carry out activities related to the essence of the profession concerned.

Such an approach to a liberal profession is primarily related the services of a freelancer. K. Wojtczak's doctrinal definition according to which the liberal profession is a personal and independent perfornce of an internally coherent set of intellectual, highly qualified (knowledge and practice) activities, systematically, in return for a selflessly determined fee, to provide benefits or services to clients, values of the general interest, in accordance with applicable legal norms, ethical and deontological principles [3, p. 95].

Taking into account these provisions related to the concept of liberal profession and its definition, all medical professions should be considered liberal occupations. These medical professions are of public trust as indicated by the nature of the constitutional regulations discussed and the statutory distinction of a corporate nature [7, p. 12]. K. Wojtczak states that the essential element of functioning is the existence of a professional corporation [6, p. 41].

Professional independence can be understood as intellectual freedom in the decision-making process of treatment and therapy. This autonomy may be constrained in the case of employee and organizational subordination in connection to the exercise of medical professions in medical entities and other entities in which health care is provided. However, the designation of statutory independence provides guarantees of independence in making decisions related to the proper performance of benefits in spite of obligations arising from a service or contractual relationship. This is justified by the commitment to 
pursuit of the profession with due diligence, in accordance to professional ethics, respect for the patient's rights, care for his or her safety, and the use of current medical knowledge. Such self-reliance should be guarded by a medical corporation, which, while controlling the pursuit of the profession, must pay attention to every manifestation of law violation.

\section{The normative scope of professional duties}

Competency catalogues of the members of medical corporations have mainly been defined in the laws regulating medical professions. In the case of doctors, the legal scope of their professional duties is presented in a relatively general way. According to art. 2 of the Act on the profession of doctor and dentist, performing the profession of doctor consists in granting by the person who has the required qualifications, confirmed by appropriate documents, health services, in particular: health examination, diagnosis and prevention, treatment and rehabilitation of patients, medical advice and also issuing opinions and medical certificates. As far as nurses are concerned, the law is wider than that of doctors. According to art. 4 of the Act on the profession of nurse and midwife, performing the profession of nurse consists of providing health care services, above all the followings:

- recognizing the patient's condition and health needs

- recognizing patient care issues

- planning and administering patient care

- self-giving in a given range of benefits: preventive, diagnostic, therapeutic, rehabilitation, and medical emergency services

- execution of medical orders in the process of diagnosis, treatment and rehabilitation

- making a decision on the type and scope of nursing care

- health education and health promotion

The best formulated was the physiotherapist catalogue, regulated in art. 4 sec. 2 on the physiotherapist's profession act. It is broadly formulated as following:

- functional diagnostics of the patient

- qualifying, planning and conducting physiotherapy

- qualifying, planning and conducting kinesiotherapy

- classifying, planning and conducting a massage

- commissioning of medical devices

- matching patients' medical devices

- teaching patients how to use medical devices

- health promotion 
- issuing opinions and judgments on the functional status of persons undergoing physiotherapy and the course of the process physiotherapy

- teaching patients the compensation mechanisms and adaptation to the altered potential of body functions and activity

The pursuit of the medical profession on your own account involves the fulfilment of the requirements of the Healthcare Institutions Law. The most important requirements include:

- the obligation to make public the information on the extent and types of health services provided

- banning advertising

- the obligation to provide health care to a person who needs immediate care due to life threat or health issues

- the obligation to have rooms and facilities which meet the requirements of the general public, sanitary and installation standards appropriate for physiotherapeutic activities

- the obligation to use products conforming to the requirements of the Act on medical devices

- the obligation to ensure the provision of health services exclusively by persons performing medical profession and meeting the health requirements specified in separate regulations

- the obligation to sign a civil liability insurance contract covering damages arising of the provision of health care services or the unlawful abandonment of health care benefits

The prescribed competency requirements for performing medical professions are limited to medical issues related to the provision of health services. Running a business activity in the form of an individual practice involves additional normative obligations of a general nature which must be respected by all entrepreneurs.

Lastly, the normative obligations for the medical profession must be listed as defined by the Patient Rights Act of November, 62008 and the Patient Ombudsman (Journal of Laws 2009, No. 52, item 417). It is worth to emphasize that the rights of a patient regulated by a legal act largely correspond to the competences laid down in the medical professions law and, above all, the law on the profession of doctor and dentist. The most important rights of the patient are the main guidelines for medical practitioners and are defined in Art. 6 of the established law on right to health care benefits corresponding to the current medical knowledge, the right to the opinion of another doctor or nurse and the right to consult. In addition, Article 8 of the Act gives the patient the right to have health care services provided with due diligence by health care providers under conditions that meet specific requirements and the right to 
have benefits in accordance to the professional ethics of the representatives of the medical profession concerned. Therefore, the patient's rights also represent an obligation to medical practitioners to provide health care services. However, the enactment of the Patient Rights Act and the Patient Ombudsman was not particularly relevant for the legal status of patients because their rights are at the same time the duty of doctors, nurses and physiotherapists resulting from the presented laws and codes of medical ethics.

\section{The postulated extension of the normative scope of medical pro- cedures}

The Act on Healthcare Institutions Law introduced in Art. 22 sec. 5 the optional possibility of introducing under the Health Minister's Ordinance the standards of medical treatment in selected fields of medicine or in certain entities performing medical activities. The motivation for normative standardization is, according to the mentioned recipe, the need to provide adequate quality of health services. So far, only low standardization has been decided on the provision of health care services. The following regulations were issued:

- The Ministry Of Health regulation of September 20, 2012 on standards of medical procedures for the provision of healthcare services in the context of prenatal care performed on a woman during physiological pregnancy, physiological childbirth, puerperium and neonatal care

- The Ministry Of Health regulation of December 20, 2012 on standards of medical treatment in the field of anaesthesiology and intensive care for practitioners

- The Ministry Of Health regulation of November 22, 2013 on guaranteed benefits for long-term care and nursing care

It seems appropriate to continue working on the introduction of further health care standards. Progressive standardization is necessary for the proper implementation of patient rights and proper provision of health care services. Standardization is certainly a method for improving the quality of medical services. Of course, it will not guarantee the elimination of so-called undesirable phenomena in the health care process, but will certainly reduce it. Moreover, if the undesirable phenomenon takes place, its evaluation will not depend only on the authoritative expert assessment but also on the implementation of normative procedures.

The introduction of postulated standardization will also have a desirable dimension for medical staff whose competence will be regulated in detail. Making decisions in the standardized health care process is less risky and therefore less responsive. Professional corporations should also play an important role in the process of standardization. 


\section{Conclusions}

The process of regulation of health and medical law in Poland is continuous. It seems to still be far away from its full adjustment to the health system. There is the need to not only normalize the procedures but also to streamline the execution of the medical professions. The further development of the Polish health care system should be based on its actual substructure, which determines the actions of the members operating in the system. The range of health services must be specified as well as the competence of the persons responsible for the organization of the payment system according to constitutional requirements of equal access to health services. However, the services and the work of representatives in the medical professions seem to be settled, but, as noted in this chapter, management data is not perfect.

\section{References}

[1] J. Boć (ed.), Konstytucje Rzeczypospolitej oraz komentarz do Konstytucji RP z. 1997 $r$. [Constitution of the Republic of Poland and a commentary to the Constitution of the Republic of Poland of 1997]. Wrocław, 1998.

[2] D. Karkowska. Komentarz do ustawy o prawach pacjenta $i$ Rzeczniku Praw Pacjenta. Komentarz, [Commentary on the Law on Patient Rights and the Patient Rights Ombudsman. Comment]. Warszawa, 2012.

[3] D. Karkowska. Prawo medyczne dla pielegniarek [Medical law for nurses]. Warszawa, 2013.

[4] D. Karkowska. Zawody medyczne [Medical professions]. Warszawa, 2012.

[5] S. Poździoch. Prawo zdrowia publicznego. Zarys problematyki [Public health law. Outline of the problem]. Kraków, 2004.

[6] K. Wojtczak, Zawód i jego prawna reglamentacja. Studium z. zakeresu materialnego prawa administracyjnego [Profession and its legal regulation. A study in the field of substantive administrative law]. Poznań, 1999.

[7] A. Krasnowolski, Zawody zaufania publicznego, zawody regulowane oraz wolne zawody. Geneza, funkcyonowanie i aktualne problemy. Biuro Analiz i Dokumentacji. Zespół Analiz i Opracowań Tematycznych. Kancelaria Senatu [Public trusts, regulated professions and free professions. Genesis, function and current problems. Analyzes and Documentation Office. Team of Analyzes and Thematic Studies]. Senate Chancellery. Warszawa, 2013.

[8] Stanowisko Nr 6/15NII PREZYDIUM NACZELNEJ RADY LEKARSKIEJ z dnia 30 stycznia 2015 r. w sprawie projektu ustawy o zawodzie fizjoterapeuty oraz o zmianie innych ustaw wraz z autopoprawka. [Statement on the draft act on the physiotherapist's profession and on the 
amendment of other laws together with the self-amendment]. Warszawa, 2015.

[9] Z. Snażyk, Opinia prawna z dnia 3 lutego 2015 r. na temat projektu ustawy o zawodzie fizjoterapenty oraz zmianie innych ustaw [Legal Opinion of 3rd of February 2015 on the draft Act on the physiotherapist and other act]; druk sejmowy nr 3001. Warszawa, 2015. 